Wildfire Damage Reduced on Prescribed-Burned Areas in New Jersey E. B. Moore, G. E. Smith and S. Little.

Effects of the Forest Floor on Disposition of Rainfall in Pine Stands - P. B. Rowe.

Conversion of Brush to Grass on a Burned Chaparral Area - Gustaf Juhren, Rupert Pole and James O'Keefe.

Pruning to Different Heights in Young Douglas-Fir - William I. Stein.

The Effect of Oak Wilt on the Cold-Soak Treatability of Oak Fence Posts - C. S. Walters, B. M. Zuckerman and W. L. Meek.

The European Pine Sawfly on the Henderson State Forest, Illinois, with Notes on its biology and control — Daniel M. Benjamin, J. Donovan Larson and Arnold T. Drooz.

Black Walnut Responds to Pruning - F. Bryan Clark.

\title{
Publications Of The Forest Research Division 1
}

\section{Technical Notes}

This series provides for publication of findings on the results of individual research projects or experiments and may provide for advance publication of selected information which may be incorporated later in a Forestry Branch Bulletin. Technical Notes will be issued in a single numerical series, which will embrace publications prepared by Sections of the Division dealing with silviculture and management research, forest inventories research and forest fire protection research. Technical Notes are distributed without charge to persons whose names appear on the appropriate mailing list of the Division.

\section{Forestry Branch Bulletins}

Reports of major importance are issued as Forestry Branch Bulletins, a charge will be made for all future editions of publications in this category and may be purchased from the Queen's Printer, Ottawa. Notification of publication of each bulletin, including sales price, will be mailed to all persons whose names appear on the mailing lists of the Forestry Branch.

\section{Miscellaneous Publications}

This series embraces a limited number of publications not covered by the above described classes and for which a charge may or may not be made.

\section{Periodicals}

This group includes annual statements on "Forest Fire Losses in Canada" and semi-annual issues of "Forest Protection Abstracts". Distribution will be made to persons on the appropriate mailing list.

\section{Reprints}

Reprints of articles contributed to various journals are available from time to time and may be distributed to persons on the appropriate mailing list or made available on request only according to the nature of the material.

\footnotetext{
${ }^{x}$ Department of Northern Affairs and National Resources, Forestry Branch.
} 